\title{
Just Telling It Like It Is? Representations of Teenage Fatherhood in Contemporary Western Young Adult Fiction
}

\author{
Michelle Gill
}

The word "father" scares the life out of me. How can I be a father at sixteen, seventy miles away from a girl I hardly know and a baby I've never seen?

(Reckless 2002, p.160)

Baby hands. Warm, sweet-smelling baby hands. And all I can do is kiss them and pull her closer so she won't see my face and how scared I am.

When there's nothing you can do, do nothing.

But then I realize. I've done it. I know something. I know something about this little thing that is my baby. I know that she needs me. I know what she does when she just needs me.

(The First Part Last 2003, p.15)

The above quotations offer two fictional representations of teenage boys, both boys are afraid of 'fatherhood', worried about whether they can, or actually want to, take on the role. However, their fears are subtly different. In Reckless (Mayfield, 2002), Josh has yet to meet his new born son, Sam, and so his concerns centre around his perception of a cultural understanding of what it means to be a father. He perceives his youth, non-resident status and consequently, lack of ability to provide, as absolute barriers to his role as a 'good' father. Bobby in The First Part Last (Johnson, 2003) is sole carer to his daughter, 'Feather', after complications during the birth leave his girlfriend Nia in an irreversible coma. Billy is fearful of his inadequacy in meeting the daily needs of his daughter in terms of the emotional strength which this demands from him. However, he comes to realize that the deep bonds which exist between them make him a parent in ways which cannot be articulated through language and are beyond social discourses regulating 'good' or 'bad' ways of being a father.

In this paper I will introduce a number of fictional narratives, written for a young adult audience, which address the experience of teenage parenthood from the perspective of the teen father. In doing so, I will consider how the narratives interact with dominant ideological understandings of fatherhood in Western societies at the end of the twentieth and beginning of the twenty-first centuries in order to explore the various experiences which the texts potentially offer to the reader and how they work to support or challenge privileged ideas about being 'a good father'.

\section{The fatherhood debate and the politics of fatherhood: father as 'breadwinner'}

Within Western societies teenage parenthood is positioned as disruptive and teen fathers specifically remain an enigmatic, disparate group. Kiselica and Sturmer (1993) suggest that one of the reasons why teenage fatherhood is considered problematic is because teenage boys are not able to participate in culturally constructed understandings of normative fatherhood:

Until the 1980s, scant positive attention was devoted toward teenage fathers in the social sciences literature. Robinson (1988) suggested that such treatment reflected societal stereotypes that depicted teenage fathers as psychologically maladjusted youths who first sexually exploited adolescent girls and then abandoned them and their children. This perception of teenage fathers is at odds with the cultural expectation that fathers accept the responsibilities of emotionally and financially supporting their children.

(p. 487)

This statement suggests some compelling reasons for the absence of teenage fathers in professional literature, one consequence of which is that very little is known about them as a group and practical support services are not provided for them. In making this statement, however, assumptions are made about 'normative' fatherhood; that is, fathers are expected to 'emotionally and financially' (p.487) support their children. This statement contains a number of complex, often contradictory, discourses as the two states 'financial provider' and 'caregiver' are often at variance in Western capitalist societies which privilege the nuclear family structure, with its associated gendered spaces, through which capitalism is able to maintain its prerogatives (Morgan 1996).

The gendered spheres of work and home are recognized as having become increasingly polarized during the period of the Industrial Revolution and its aftermath, specifically in middle-class households where women and children were 
not required to support the household income. However, Kimmel suggests that the nuclear family with its absence of kinship and support networks is a phenomenon of the post-World War II era, specifically the 1950s. Although he asserts that it began to crumble under its own weight of expectations almost immediately, it has nevertheless remained the ideologically idealized family structure under whose expectations subjects are expected to conform and labour (Kimmel 2004, p.125). One of the contradictions at the heart of this family discourse is that by making it the space where the emotional needs of all family members are met, a conflict of interest is created in that it must also provide financially for them. In order to meet these diverse expectations men and women were initially positioned in opposing gendered spaces: father as breadwinner and mother as carer. As suggested in the work of David Morgan (1996), the economic imperative of capitalist societies dictates structures within the private sphere but in so doing problemizes the role of parent. Formally this conflict of interest related in the main to fathers who worked outside of the family sphere. But since the inception of second wave feminism, women who have returned to paid employment outside of the home have found themselves negotiating the demands of work and family life, specifically choices around parenting.

While potentially presenting fathers with conflicting choices, the discourse of father as breadwinner remains deeply desirable to many men as it interacts with dominant constructs of masculinity which privilege those who successfully navigate the challenges of hierarchical capitalist societies and are rewarded with their share of what Connell terms 'the patriarchal dividend' (Connell 1995, p.79). However, in sustaining the capitalist ideal not all men can share equally. Those of lower status are usually working-class men, men from ethnic minorities, gay men, or others who are dispossessed due to illness or disability. Specifically in relation to the discourse of father as breadwinner, young men and boys are disempowered through their lack of ability to generate income. As a consequence, in Western societies, the possessors of privileged masculinity are generally white, middle-class men whose status is maintained through power invested in hegemonic cultural discourses and actual practices of government and law. (Connell 1995)

Fatherhood, then, is a site of contested discourses which at once suggest that 'good' fatherhood practices incorporate both financial and emotional investment in children. At the same time capitalist societies prioritize the breadwinner role in order to stabilize and maintain its means of production. This potentially positions some men in opposition to other men and women and children in the pursuit of desirable masculinity and the status it brings.

In a number of the fictional narratives of teenage fatherhood to be discussed in this paper financial provision is presented as a problematic arena. Margaret Bechard's Hanging On To Max (2002) relates the story of Sam who is a single parent teenage dad at the age of seventeen after he splits up with girlfriend Brittany who wants to have the baby adopted. The story unfolds through Sam's first person narration - the use of direct address positions the reader alongside him, sharing his fears and frustrations. Sam is a top grade student but makes an agreement with his own father that he will take a job with a construction company after he finishes high school so that he can repay his father for 'keeping' him and baby Max during his last year at school. Sam's high school counsellor questions him about taking college entrance exams in order to keep his options open:

"I'm not going to college, Mrs. Harriman. That's not the deal. My dad and I...we've got this figured out. I'll work construction." I'll take responsibility.

"I understand that, Sam. But part of my job is to make sure you're aware of your options. Is working construction what you want to do?"

(Bechard 2002, p.29-30)

Although Bechard represents Sam as outwardly trying to be a 'responsible' parent, that is, providing and caring for his son, the reader at the same time also has access to his increasingly confused and unhappy feelings. While rationally telling Mrs Harriman what he is going to do with his future he is simultaneously regretting what he has lost:

Like I had options. Like any of this was what I wanted to do. Like I'd always dreamed of being a 
dad at seventeen. And the funny thing was, I had known what I wanted to do. I'd known exactly what I wanted to do...I was going to go to college. Major in engineering. Work with computers...

(p. 30)

By making Sam the focalizer in the narrative, Bechard ensures that the reader can empathize with his dilemma; that financial responsibility for Max will consign Sam to a career choice he does not want to take. The situation he finds himself in means that he has to give up his own dreams for the future to care for his son.

Through the unfolding of Sam's internalized story Bechard suggests to the reader that parenting for a young man, not long out of his own childhood, is a complex, difficult path in terms of both financial and emotional investment; Sam's understanding of fatherhood, learnt from his own father and how he perceives the outward behaviour of other fathers he knows, makes it more difficult for him to ask for help because to do so makes him feel that he has failed in some way.

Another young fictional father who struggles to provide is Matt in Joanne Horniman's Mahalia (2001). Matt too is a single parent but he has opted out of education, leaving school at the first opportunity. He lives on a social security allowance which barely pays for basic food and rent so life for him is a constant struggle simply to survive. He spends his days in a never ending round of caring for his daughter, Mahalia, and trying to find enough to eat. At one point he is forced to pawn his guitar which represents his only interest outside of Mahalia. He eventually finds a job in a café but doesn't have any structured childcare meaning that he has to rely on friends who have other priorities:

"How was she?" he asked breathlessly, arriving in the kitchen where Eliza was setting out food on the tray of her highchair. Mahalia greeted him with a squeal and a wave of her arm.

Eliza gave him a surly look. "Okay. I had to come home from the Con, though, and miss a whole day's classes."

"You could've sat her beside you on the floor."

"Yeah. Right. And you could've sat her on the floor of the café while you worked. She needs attention,
Matt, you know that. She kept wanting me to pick her up and talk to her. She wanted food all the time. Her nappy needed changing."

Matt stared at Eliza. "You're angry at me."

"You just didn't think."

"But, hey, Ineeded this job. I had to take it straight awayor someone else would have. I'll get someone else for tomorrow."

(Horniman 2001, p.118)

No consistent help arrives and the job falls through. Like Sam, Matt is shown as finding it difficult to ask for help, believing that he should be responsible for Mahalia and take care of her needs. Otherwise, he is not living up to his responsibilities as a father.

Horniman also makes Matt the novel's focalizer and while Mahalia is not told in the first person, the reader is privy to Matt's innermost thoughts and is encouraged to empathize with his struggles and frustrations. Because Matt does not have career ambitions he does not face the same dilemma as Sam about his future prospects but he does share the fear of lacking a personal identity. Both boys are shown as having to lose contact with friends they were close to before they became fathers; the focus of their worlds has changed and both find themselves ambivalent:

He had Mahalia to look after, and the routine of caring for her was his life now. Millstone, he sometimes whispered to her, Ball and chain. He didn't know whether he minded, not yet, for it was all still so new, and difficult, and he knew that he had no choice.

(Horniman 2001, p. 38)

In these texts, then, fatherhood moves beyond concerns about practical provision although this continues to be the dominant discourse outside of fiction. While both authors describe their teen fathers as struggling with financial commitments, the fact that they foreground other concerns as having more impact on the father/ child relationships in the novels indicates a subtle subversion of the normative discourse of 'good' fathering. Both Horniman and Bechard represent their teen fathers as struggling to balance their lives. Both characters are depicted as being conflicted: they 
are committed to their children while also unsure about the cost to themselves as individuals.

\section{The fatherhood debate: father as 'caregiver'}

While Matt feels ambivalence towards Mahalia, he is also acutely aware of her physical and emotional absence while he is working:

She babbled her baby talk and he replied to her, but in a subdued way, because he was so tired, and sad too, in a way he couldn't fathom. He'd been working so fast and furiously he'd had no time to think of her, but now they were together he was aware that he had missed her. What had she done today?

Horniman, here, uses fiction to explore the complex relationship between financial considerations and physically/emotionally nurturing a child, in ways that make readers aware that these aspects of fathering do not necessarily complement each other, but create contradictory needs and allegiances.

The discourse of 'the new man' which contains within it 'the nurturing father' became increasingly visible in popular culture during the 1990s and as such prioritized the role of father as caregiver with the expectation that fathers would participate fully in family life. Lupton and Barclay (1997) suggest that this offers fathers the opportunity to move beyond the breadwinner role and in so doing embrace a feminine masculine:

\begin{abstract}
Both 'expert' and more popular discourses on masculinity have tended to argue that men should take on a more 'feminine' approach in interacting with theirfamily, including revealing their emotions to their partners and children, demonstrating their love and affection openly and participating in embodied caring activities with their young children.
\end{abstract}

(Lupton and Barclay 1997, p.19)

Already problematic in relation to the breadwinner discourse, the feminine masculine represents further potential challenges to hegemonic masculinity which is validated through its position as 'other' to the feminine and as such represents a discourse of fundamental difference between masculine and feminine. Adams and Coltrane (2005) suggest that the socialization of boys into this rigid gender regime creates and maintains boundaries from an early age:

From early in their youth, we teach them (through, for instance, toys and sports) to symbolically correlate competition, violence, power, and domination with masculinity. Finally, we actively insist on their separation from mothers (in effect, their separation from anything feminine thatmight sully their budding masculinity).

(Adams and Coltrane 2005, p.237)

The authors further suggest that by defining the family sphere within the confines of the feminine, boys and men are actively encouraged to position themselves away from this space into the wider, and by implication, masculine sphere with its attending privileges. In terms of building relationships within the family this has the potential to leave men and boys 'performing' a role without the ability to become emotionally involved in relation to others or, as represented by Sam and Matt, may create feelings of anxiety about the loss of self when intimately engaged. In other fictional representations of teenage fatherhood there are examples of young men who although involved in what is happening to them find it difficult to share their emotions with anyone else. One example is Berlie Doherty's Dear Nobody (1991) in which Chris, the prospective father, finds it difficult to share his feelings about the news that his girlfriend Helen is pregnant and relies on banal responses which reiterate what he thinks he should say rather than what he actually feels:

"It'll be alright." I kept saying. "I'll stay with you whatever happens." The words just came out. I've no idea what I meant by them. When I thought about them afterwards I went cold and scared inside but at the time it seemed to be the only thing to say so I said it.

(Doherty 1991, p.30)

The concept of male emotional literacy is embedded in the discourse of 'masculinity in crisis' which became increasingly visible in both men's studies and the popular press in the 1990s (Whitehead 2002; Segal 1997). As I 
have shown, a number of recent YA novels interrogate these claims as they relate to young fathers, using fiction to give expression to the anxieties and fears they seem reluctant or unable to express. Josh (Reckless), Chris (Dear Nobody), and Sam (Hanging On To Max) all work out their frustrations through physical exertions: Chris through punishing physical exercise; Sam through basketball; and Josh through dangerous bike stunts which climax in him breaking his collar bone. By showing these boy characters as trying to evade their emotions this way, the authors suggest that some young fathers may find it difficult to articulate their feelings. This mirrors the argument put forward by Adams and Coltrane about socialization into masculinity for young boys and its implications for emotional engagement (Adams and Coltrane 2005, p.237). However, at the same time Mayfield, Doherty and Bechard all give the reader access to the boys' inner emotional turmoil though narrative focalization which challenges socially constructed representations of the teenage father suggested earlier in the work of Kiselica and Sturmer. In Reckless, Mayfield uses a dual subject narrative to explore simultaneously the reactions of Josh and his twin sister Rachel to the unplanned pregnancy at the centre of this text. Josh is initially unable to accept the situation and tries to ignore what is happening by cutting off all communication with Charlie, the mother of his son, Sam. Rachel is left to maintain contact and encourage and then bully him into telling their parents about the baby. Josh becomes more uncommunicative to the outside world as the pregnancy advances in an attempt to detach himself from what is happening. In recognition of this withdrawal, his entries become shorter than Rachel's and the reader is left to rely on her narrative for an understanding of what is happening. However, Josh's short entries frequently allow the reader to reinterpret Rachel's understanding of his behaviour and, by default, the way in which his actions could potentially be misunderstood by society in general:

(Rachel) It was the first time I'd been in Josh's room for a while. I noticed that the photo of him and Charlie had disappeared from his notice board. I wondered if he'd put that in the bin too.

(p.108)
(Josh) I took the photo of Charlie down off the wall. I put it in the drawer-face down. I couldn't handle her grinning at me all the time. It made me feel bad. We both look so cheerful and happy. I wonder what she looks like now. I don't want to think about it.

(p.115)

Although the authors construct Josh, Chris and Sam as finding it difficult to articulate their feelings they are eventually able to express their fear and pain and make decisions about the future when given the time and space to come to terms with their situations within the texts. Ultimately for each of them fatherhood becomes a matter of personal choice; they must decide honestly the relationship with their child. The authors of the texts do not advocate specific choices as right or wrong but present complex dilemmas for each of the young fathers, allowing the reader to empathize with their situations and the decisions they eventually make.

\section{The discourse of fatherhood: the problematic nature of teenage fatherhood}

As suggested earlier with reference to the work of Kiselica and Sturmer, outside the pages of YA fiction teenage fatherhood is stigmatized partly because young fathers cannot successfully conform to normative discourses of fatherhood. The novels I have discussed all represent the breadwinner discourse as especially challenging to young men who lack the means to provide financial assistance. However, in society the complexities of combining the roles of breadwinner and carer can prove problematic for many men, not just the very young; yet, teenage fathers as a group are specifically targeted for cultural vilification. This is due to a perception of them as emotionally absent, abandoning young girls and their children as unwanted reminders of their sexually predatory nature, an issue which Kiselica and Sturmer specifically draw attention to in explaining why young fathers are frequently overlooked in official research and subsequently become a voiceless, unknown group (Kiselica and Sturmer 1993, p.487).

Historically boys have been blamed for teenage pregnancies, the perception being that they are unable to control themselves and consequently pressure girls 
into sexual relationships. However, the construction of heterosexual masculinity is consistently validated through discourses which privilege sexual performance over emotional engagement. In an ethnographic study, which explored the ways in which masculinity is both socially constructed and policed in a British state school, Mac An Ghaill(1994) found that young males adhere to 'compulsory heterosexuality' with reference to other males in order to validate their gender performance. Specifically in relation to sexual relationships:

Their sexual narratives carried the predictable misogynous boasting and exaggeration of past heterosexual conquests and male heroic fantasies, in which women were represented as passiveobjects of male sexual urges, needs and desires. These male 'fictions' appeared to be crucial elements in setting the parameters of the prescriptive and proscriptive sex / gender boundaries that served to police schoolboys 'performance by making them act like men.

(Mac An Ghaill 1994, p.92)

Masculinity performances, then, are regulated so as to achieve desired heterosexuality status amongst peers. In this scenario heterosexuality is constructed through competitive, action biased narratives which negate and therefore devalue emotional engagement. This masculinity is further valorised and endorsed in Western cultures through the representation of 'successful' men in entertainments such as film and sport. It is therefore somewhat ironic that boys who find themselves as fathers prematurely because they validate their heterosexuality through sexual experiences are then described as predators and exploiters in discourses relating to teenage pregnancy.

Berlie Doherty's Dear Nobody constructs its teenage father, Chris, as feeling that he is blamed and stigmatized when Helen's mother bans him from their home, effectively stopping him from having any involvement with the pregnancy:

$$
\begin{aligned}
& \text { "Hiya you," I said. } \\
& \text { "It's not Helen. She's asleep. Mrs Garton said. I } \\
& \text { looked at my watch. It was eighto clock. "Listen," } \\
& \text { she said, lowering her voice. It sounded as if she } \\
& \text { was hissing down the phone, but I thinkshewas only }
\end{aligned}
$$

trying to keep her voice down so nobody could hear. But it made my skin creep, the way she hissed, and what she said to me. "She's told me everything. I want you to know that you're never to come to this house again. Do you understand?"'

(Doherty 1991, p.63)

What Chris understands is that he is being blamed for the pregnancy despite the fact that the sexual encounter which leads to the pregnancy is a first experience for both him and Helen. Doherty does not represent him as predatory; in fact he is positioned as deeply involved and committed to the relationship. By constructing Chris in this way, while at the same time making visible the stereotype of the teenage father, implied in the words and behaviour of Helen's mother, Doherty challenges the cultural understanding of the teen father as predatory and sexually experienced. In the group of fictional texts under discussion, although relationships between the boys and their partners usually flounder, there is no suggestion of the pregnancies arising from casual, meaningless sexual encounters, leaving the young men unconcerned about the consequences. Josh's (Reckless) relationship with Charlie is initially the least committed as a holiday romance. He concedes:

Inever thought she would get pregnant. That was the last thing on my mind. She was gorgeous and it was summer and I couldn't keep my hands off her. What did that have to do with babies. Sod all.

(Mayfield 2002, p.87-88)

However Mayfield does not present him as someone who is able to walk away from the situation without any thought as to the consequences. By giving the reader access to Josh's thoughts through the use of a dual focalization, she allows his mounting panic and vulnerability to become visible. In the character of Josh she disrupts the stereotype of the teenage father as uncaring and unengaged.

In Dear Nobody, Berlie Doherty also confronts preconceptions about the teenage father. Chris, like Sam (Hanging On To Max) is an educational high achiever. The social stereotype of teenage fatherhood involves not only the assumption of sexual experience but also suggests a class prerogative in that working-class boys are perceived as being most likely to become fathers 
at a young age. This does not mean that there are not some truths behind the image; statistics show that teen fathers often come from economically-impoverished backgrounds, frequently have low levels of educational achievement and are often involved in drugs and other criminal activity which ends with them spending time in young offenders' institutions (Thornberry 1997, p.505). However, in making her character academically able, Doherty introduces uncertainty into commonly held social assumptions, challenging the reader to reconsider the dominant image. By structuring the narrative so that the reader travels on the journey with Chris, Doherty allows empathy and understanding for his situation to grow, further undermining the landscape of teenage fatherhood as belonging to a 'shady', unknown underclass.

John Beynon identifies four themes through which masculinity was consistently represented and examined in the broadsheet press and popular literature around the beginning of the new millennium (Beynon 2002). One of the themes identified relates to what he terms 'men running wild':

This group of discourses expresses a fear of rampant, untamed masculinity, of men running wild, and either behaving in an irresponsible way sexually and therefore, failing to take seriously their responsibilities as fathers, or literally being out of control.

(Beynon 2002, p.128-9)

The teenage father, positioned within this discourse, becomes enmeshed in a cultural 'moral panic' in which an underclass living outside of regulated society is perceived as a threat to both physical and moral wellbeing. Martin Waddell's Tango's Baby (1995) tells the story of a teenage father living in such an underprivileged environment. Unlike the subjects of the other texts addressed in this paper, Tango is without agency; his story is told by his friend Chris. Tango, then, represents the stereotype of the voiceless young father about whom little is known and his actions are therefore open to interpretation or misrepresentation as Chris concedes:

A lot of people have said and written things about Brian Tangello, most of them not true. Tango 's side of things ought to be told, but Tango being Tango, it never will be now. No one would listen if he tried to tell it his way, so I'm telling it mine, and this is the result - the might-be-true story of Brian Tangello and Crystal O'Leary.

(Waddell 1995, p.8)

In the course of the narrative Chris recounts the story of Tango's relationship with Crystal, the birth of baby D. and the subsequent breakdown of the relationship when Crystal meets some-one else. In his fear of losing baby D., Tango takes the baby and hides out refusing to return him until he is surrounded by police and is left with no choice. His actions result in a jail sentence and his subsequent demonizing in the press:

The TV and tabloids had their day, at Tango's expense. Most of the stuff they printed was rubbish; the Loop came out as a sink estate, and we were all joyriding junkies living off the Welfare.

(p.185)

Through the narrative structure Waddell highlights social assumptions made about the connection between teenage fatherhood and poverty as an indicator to criminal activity. However, because the narrative is related by Chris, Tango is given no space in which to explain his actions, meaning that the events remain unresolved and the reader is left with no clear understanding of Tango's intentions. For this reason Tango's Baby must ultimately be considered as upholding prevailing social discourses about teenage fathers; Tango's actions remain open to interpretation and his construction as a young man who has 'failed' in school, is involved in criminal activity, living on a 'sink' estate, serve to position him within the commonly held perception of the teenage father and as such, Waddell re-enforces this image through the narrative.

The teenage father in society is generally constructed in negative terms because not only does he challenge discourses of normative fatherhood but also he is considered a potential sexual predator, part of a moral panic in which masculinities are perceived as out of control and in need of regulation. However, with the exception of Tango's Baby, the recent group of teen father fictions under discussion represent examples of texts which challenge socially 
constructed stereotypes and make visible alternative experiences of young fatherhood in ways which encourage the reader to reconsider common assumptions through his/her empathy with the fictional teen dad.

\section{The discourse of fatherhood: teenage fatherhood as an individual lived experience}

By allowing space for the subject to express his emotional response and explain his actions, the authors of these novels offer readers an opportunity to reassess socially constructed stereotypes and understand fatherhood as a unique experience for each young father. In the case of Josh (Reckless), Mayfield does not offer any easy solutions to the situation but simply by giving space to Josh she allows the reader to experience the complexity of the dilemma faced by the boy father. She shows, through the use of a dual narrative, that silence does not represent lack of interest or engagement.

When Sam (Hanging On To Max) decides to give up Max for adoption, he accepts that he isn't yet ready to be responsible for a child and needs to experience more of life. In giving the reader access to Sam's emotional turmoil, Bechard creates understanding for Sam's predicament which means that the reader is able to accept his decision to have Max adopted without judging him. Sam tries hard to care for his son and loves him deeply; the reader is given verification of this through both his words and actions. When Max hurts himself with some broken glass, Sam is revealed as panic stricken and wracked with guilt:

\begin{abstract}
"What happened? What happened?" Glass crunched under my feet as I crossed to them and snatched Max out of Jenny's arms. I tried to cradle him, tried to see where all the blood was coming from, but he thrashed and wiggled in my arms...
\end{abstract}

There was blood on my hands, on my shirt. "But where..." I couldn't seem to get my breath, and my heart was beating so hard it hurt. "I can't see..."

(Bechard 2002, p.122)

Sam feels guilty because he was outside enjoying himself with his friends when the accident happened instead of looking after Max. He feels that whatever he does will never be good enough which is part of the reason he decides to have Max adopted. However, Bechard further endorses his decision when the reader is given a snapshot of the future; at the end of the narrative Sam has married and has two daughters. He is working in the career he originally chose for himself. A young man comes looking for his father:

He comes walking up the driveway. He's tall and kind of skinny. Broad shoulders. Football player, maybe. Maybe hockey. Brittany's big blue eyes. Blond hair. Curly hair. He smiles as I set down my fishing pole.

"Hi", he says. He holds out his hand. "I'm Max".

(p. 142)

\section{Sam is given another chance with his son.}

In The First Part Last, Angels Johnson introduces Bobby, a single father, who she constructs as intensely involved in the physical and emotional wellbeing of his daughter Feather. At the same time, he does not find the role of father easy and is ambivalent about his situation because he feels as if he has lost a part of his individuality, similar to the relationship which Horniman constructs between Matt and daughter Mahalia: 'I walk to my room, put Feather in her crib, which pisses her off and makes her scream, and then I look around my room and miss me (Johnson 2003, p. 35).

Throughout the narrative there is a sensation of exhaustion emanating from Bobby because he cannot get enough sleep. However, Johnson's use of humour signals to the reader that although it is a serious problem, Bobby will somehow cope and persevere:

I was up all night with Feather, who thinks that two in the morning is partytime...

It's cool when I talk to her. I could be saying anything. I could be talking about basketball or my bad grades in math...

As long as my mouth is moving, she's happy. As long as sound is coming out of it, the whole world is just fine for my caramel, sweet-faced, big-eyed baby; who's killing me, and keeping me so tired I can't keep my eyes open.

(p. 41-2) 
Johnson constructs Bobby as someone who keeps trying, finding reserves within himself because of the inexpressible bond and love he feels for his daughter, a bond which keeps him connected even when things become really hard. Lupton and Barclay suggest that parenting involves extrarational aspects which move beyond social constructionist theories:

We would argue that fatherhood is not only constituted through discursive and conscious processes, but importantly is also constructed through touch and smell and inchoate memories of infancy and early childhood, all of which form part of the realm of knowledge and experience.

(Lupton and Barclay 1997, p.22)

This understanding of parenting allows for the existence of a unique bond which cannot be expressed through language but which re-enforces the idea of fatherhood as an individual, lived experience and privileges a discourse of fathering which does not involve the breadwinner role but validates emotional engagement thus offering the father a way into the life of his child through the recognition of a unique, intimate bond between parent and child.

Through Bobby, Johnson enables readers to recognize and vicariously experience this important emotional connection between father and child; a bond not easily broken and which is not dictated by outside forces regulating ideas about good and bad fathering:

...I always kiss her, my baby, and look into her clear eyes that know everything about me, and want me to be her daddy anyway.

(p. 81)

In summary, then, I would suggest that with the exception of Tango's Baby, the fictional narratives discussed here offer the reader the opportunity to engage with the subject of teenage fatherhood in various imaginative landscapes which empathize with the young dads through their subject positions within the texts. The authors challenge socially constructed stereotypes which suggest that teenage fathers as a group belong to an underclass with low educational achievement and involvement in crime; boys who are sexual predators and disengaged from their children. By representing the young fathers as struggling to come to terms with their situations, the authors suggest this is a difficult situation but at the same time, one which is unique to each of the boys involved, represented by the different outcomes and resolutions which the boys arrive at.

In 2002, as part of their 'Platform For Art' series, London Underground exhibited a collection of photographs by Edmund Clark entitled 'Baby Fathers'. The pictures represented the culmination of a project which lasted for over a year during which time Clark met with teenage fathers who were prepared to be photographed with their children and talk about their experiences of fatherhood. Commenting on the photographs which he hoped might dispel some of the myths surrounding teenage fathers, Clark suggested:

These images are about the physical intimacy of fatherhood, the pleasure of holding and being close to your child... They show strong relationships which may be at odds with current attitudes to teenage fathers. I hope that they challenge people to reassess their preconceptions of a little known group.

(Clark 2002)

In the same way that Clark's photographs work to make the audience consider their own understandings or prejudices about young fathers so the fictional narratives discussed in this paper offer the reader the opportunity to think again, to reassess...

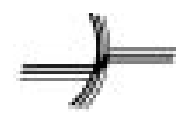

\section{REFERENCES}

Adams, M. \& Coltrane, S. (2005) 'Boys and Men in Families: The Domestic Production of Gender, Power, and Privilege', in M.S. Kimmel, J. Hearn \& R.W. Connell (eds) Handbook of Studies on Men and Masculinities. Thousand Oaks, Sage, pp.230248.

Bechard, M. (2002) Hanging on to Max. Connecticut, Roaring Brook Press.

Beynon, J. (2002) Masculinities and Culture. Buckingham, Open University Press. 
Clark, E. (2002) Baby Fathers. www.thetube. com/content/platformforart/artists/babyfathers (16.03.03)

Connell, R.W. (1995) Masculinities. Berkeley, University of California Press.

Doherty, B. (1991) Dear Nobody. London, Hamish Hamilton.

Horniman, J. (2001) Mahalia. St Leonards, Allen \& Unwin.

Johnson, A. (2003) The First Part Last. New York, Simon \& Schuster

Kimmel, M.S. (2004/2000) The Gendered Society. New York, Oxford University Press.

Kiselica, M.S. \& Sturmer, P. (1993) 'Is society giving teenage fathers a mixed message?', Youth and Society 24, 487-501

Lupton, D. \& Barcley, L. (1997) Constructing Fatherhood: Discourses and Experiences. Thousand Oaks, Sage Publications Inc.

Mac An Ghaill, M. (1994) The Making of Men: Masculinities, sexualities and schooling. Buckingham, Open University Press.

Mayfield, S. (2002) Reckless. London, Hodder Headline.

Morgan, D. (1996) Family Connections: An Introduction to Family Studies. Cambridge, Polity Press.
Segal, L. (1997/1990) Slow Motion: Changing Masculinities, Changing Men. London, Virago Press.

Stacey, J. (1996) In The Name of The Family. Boston, Beacon Press.

Thornberry, T.P. et al (1997) 'Risk factors for teenage fatherhood', Journal of Marriage and the Family 59, 505-522.

Waddell, M. (1995) Tango's Baby. London, Walker Books.

Whitehead, S.M. (2002) Men \& Masculinities. Cambridge, Polity Press.

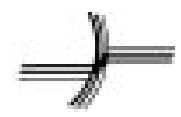

\section{BIOGRAPHICAL NOTE}

Michele Gill is a PhD student at the University of Newcastle, UK. Her thesis explores representations of masculinities in contemporary young adult fiction in relation to the discourse of 'crisis' surrounding the lives of boys at the beginning of the twenty first century. Michele is currently the young people's library services manager for the London Borough of Ealing and works as a literacy tutor with young adults who have been excluded from mainstream education. 